\title{
Effect of influenza virus infection on key metabolic enzyme activities in MDCK cells
}

\author{
Robert Janke ${ }^{1 *}$, Yvonne Genzel $^{1}$, Maria Wetzel², Udo Reichl1,2 \\ From 22nd European Society for Animal Cell Technology (ESACT) Meeting on Cell Based Technologies \\ Vienna, Austria. 15-18 May 2011
}

\section{Background}

Influenza, or "flu", is an upper respiratory tract infection caused by a virus belonging to the family of Orthomyxoviridae. Influenza can pose a serious risk to the health of mainly the elderly, the very young, and to people suffering from medical conditions (e.g. weak immune system). For example, seasonal influenza strains are fatal to more than 50,000 people annually in the United States alone [1]. The most effective measure for preventing influenzarelated morbidity and mortality is annual vaccination. Seasonal influenza vaccines are almost exclusively produced using the traditional egg-based manufacturing process. However, the main limitation of egg-based technology (especially in the case of a pandemic) is the time-consuming production process ( 6 months). Furthermore, people with serious egg allergy cannot be vaccinated when trace amounts of egg protein remain in the final formulation. Therefore, new production processes using continuous cell lines for influenza vaccine manufacturing are currently being established [2].

Influenza viruses take advantage of the host cell metabolism to replicate their genetic material and to synthesize viral proteins. The influenza virus particle consists of three major parts: the ribonucleocapsid, the matrix protein $\mathrm{M} 1$, and the envelope, which is derived from the plasma membrane of the host cell. The lipid bilayer contains the ion channel protein M2 and the immunogenic glycoproteins hemagglutinin and neuraminidase [3]. The replication cycle of influenza viruses including entry, uncoating, genome transcription and replication, assembly and release has been studied extensively with type A strains [4]. So far, only few studies have characterized the influence of influenza infection on the central

\footnotetext{
* Correspondence: janke@mpi-magdeburg.mpg.de

'Max Planck Institute for Dynamics of Complex Technical Systems,

Bioprocess Engineering group, Sandtorstraße 1, 39106 Magdeburg, Germany Full list of author information is available at the end of the article
}

carbon metabolism of host cells [5]. Madin-Darby canine kidney (MDCK) cells are considered a suitable substrate for cell culture-based influenza vaccine manufacturing $[2,6]$. In this study, key metabolic enzyme activities were analyzed in MDCK cells infected with an influenza A virus strain to improve our understanding of virus-host cell interaction and cell response.

\section{Materials and methods}

All chemicals and enzymes were purchased from Sigma (Taufkirchen, Germany) or Roche (Mannheim, Germany). Adherent MDCK cells obtained from the ECACC (No. 84121903) were routinely cultured in 6well plates containing $4 \mathrm{~mL}$ of GMEM-based medium (2 mM glutamine, $30 \mathrm{mM}$ glucose, $10 \%(\mathrm{v} / \mathrm{v})$ fetal calf serum, $2 \mathrm{~g} / \mathrm{L}$ peptone, $48 \mathrm{mM} \mathrm{NaHCO} 3$ ) in a $\mathrm{CO}_{2}$ incubator at $37{ }^{\circ} \mathrm{C}$ and $5 \% \mathrm{CO}_{2}$ to the stationary phase $(\sim 5$ days of growth, 4.0-4.2 $\times 10^{6}$ cells) [7]. Cell concentration and viability was determined for samples from 6 well plates as described previously [8]. MDCK cells were either mock-infected or infected with MDCK celladapted human influenza virus A/Puerto Rico/8/34 (H1N1) from the Robert Koch Institute (Berlin, Germany) at a multiplicity of infection of 20 as described previously $[5,9]$. Cells were washed twice with ice-cold phosphate-buffered saline 9 hours post infection (hpi), and the complete plate was then snap-frozen in liquid nitrogen and stored at $-80{ }^{\circ} \mathrm{C}$ until further use. After thawing, samples were extracted by sonification on maximum power for $30 \mathrm{~s}$ with $1 \mathrm{~mL}$ extraction buffer [7] and kept at $0-4{ }^{\circ} \mathrm{C}$. To remove cell debris, samples were centrifuged at $16,000 \mathrm{x}$ g for $5 \mathrm{~min}$. The supernatant was used to measure the respective enzyme activities. The procedure for the enzyme activity analysis and the details for the specific assay mixes were as described previously [7]. 


\section{Results}

The maximum catalytic activities of 28 enzymes from central carbon metabolism were measured under substrate saturation using a recently developed assay platform for mammalian cells [7]. Table 1 shows the maximum metabolic enzyme activities in mock-infected and influenza A (H1N1) infected MDCK cells. The activities of different enzymes comprise several orders of magnitude. The overall range covers values from 0.24 $\pm 0.10 \mathrm{nmol} / \mathrm{min} / 10^{6}$ cells (pyruvate dehydrogenase, $\mathrm{PDH}$ ) to $10348.06 \pm 1663.65 \mathrm{nmol} / \mathrm{min} / 10^{6}$ cells (triosephosphate isomerase, TPI) in H1N1 and mock-infected cells, respectively. Highest activities $(>1000 \mathrm{nmol} / \mathrm{min} /$
$10^{6}$ cells) were found for TPI, pyruvate kinase, lactate dehydrogenase, and malate dehydrogenase, while the other activities were in the range of 1 to $500 \mathrm{nmol} / \mathrm{min} /$ $10^{6}$ cells. Very low enzyme activities, which indicate possible rate-limiting steps in the respective metabolic pathway, were found for PDH, pyruvate carboxylase $(\mathrm{PC}), \mathrm{NAD}^{+}$-dependent isocitrate dehydrogenase (NADICDH $)$, and glutamine synthetase $\left(<1 \mathrm{nmol} / \mathrm{min} / 10^{6}\right.$ cells). Significant differences in catalytic activity between infected cells and mock-infected MDCK cells were found for 9 enzymes: glucose 6-phosphate dehydrogenase and 6-phosphogluconate dehydrogenase from the pentose phosphate pathway, glutaminase and malic

Table 1 Maximum enzyme activities of glycolysis, pentose phosphate pathway, TCA cycle, and glutaminolysis in MDCK cells infected with influenza A (H1N1) compared to mock-infected cells.

\begin{tabular}{|c|c|c|c|c|c|c|c|c|}
\hline \multirow[b]{2}{*}{ Enzyme } & \multirow[b]{2}{*}{ EC number } & \multicolumn{7}{|c|}{ Enzyme activities in adherent MDCK cells ${ }^{a}$ ( $\mathrm{nmol} / \mathrm{min} / 10^{6}$ cells) } \\
\hline & & \multicolumn{3}{|c|}{ Mock-infected } & \multicolumn{3}{|c|}{ H1N1 infected } & \\
\hline \multicolumn{9}{|l|}{ Glycolysis } \\
\hline Hexokinase & 2.7.1.1 & 21.80 & \pm & 3.95 & 21.89 & \pm & 1.48 & \\
\hline Phosphoglucose isomerase & 5.3.1.9 & 465.12 & \pm & 73.94 & 456.93 & \pm & 111.90 & \\
\hline Phosphofructokinase & 2.7.1.11 & 29.28 & \pm & 6.14 & 30.56 & \pm & 2.08 & \\
\hline Fructose-1,6-bisphosphate aldolase & 4.1.2.13 & 23.62 & \pm & 3.32 & 20.74 & \pm & 8.41 & \\
\hline Triose-phosphate isomerase & 5.3.1.1 & 10348.06 & \pm & 1663.65 & 10148.62 & \pm & 698.01 & \\
\hline Glyceraldehyde-3-phosphate dehydrogenase & 1.2.1.12 & 412.90 & \pm & 73.27 & 413.61 & \pm & 31.61 & \\
\hline Pyruvate kinase & 2.7.1.40 & 1004.26 & \pm & 43.53 & 1001.92 & \pm & 112.95 & \\
\hline Lactate dehydrogenase & 1.1.1.27 & 1266.97 & \pm & 134.69 & 1302.10 & \pm & 107.37 & \\
\hline \multicolumn{9}{|l|}{ Pentose phosphate pathway } \\
\hline Glucose-6-phosphate dehydrogenase & 1.1 .1 .49 & 51.91 & \pm & 1.10 & 62.71 & \pm & 4.59 & $b$ \\
\hline 6-phosphogluconate dehydrogenase & 1.1.1.44 & 30.61 & \pm & 5.03 & 38.13 & \pm & 1.05 & b \\
\hline Transketolase & 2.2 .1 .1 & 18.63 & \pm & 6.65 & 19.19 & \pm & 2.52 & \\
\hline Transaldolase & 2.2.1.2 & 23.11 & \pm & 5.84 & 23.23 & \pm & 6.30 & \\
\hline \multicolumn{9}{|l|}{ Tricarboxylic acid cycle } \\
\hline Pyruvate dehydrogenase & 1.2.4.1 & 0.30 & \pm & 0.07 & 0.24 & \pm & 0.10 & \\
\hline Pyruvate carboxylase & 6.4 .1 .1 & 0.48 & \pm & 0.11 & 0.82 & \pm & 0.23 & b \\
\hline Citrate synthase & 2.3.3.1 & 21.55 & \pm & 1.70 & 25.40 & \pm & 2.84 & $b$ \\
\hline Citrate lyase & 2.3.3.8 & 4.48 & \pm & 0.55 & 6.00 & \pm & 0.98 & b \\
\hline $\mathrm{NAD}^{+}$-linked isocitrate dehydrogenase & 1.1.1.41 & 0.27 & \pm & 0.02 & 0.34 & \pm & 0.05 & $\mathrm{~b}$ \\
\hline $\mathrm{NADP}^{+}$-linked isocitrate dehydrogenase & 1.1 .1 .42 & 44.27 & \pm & 2.73 & 44.57 & \pm & 5.37 & \\
\hline Fumarase & 4.2.1.2 & 74.62 & \pm & 6.56 & 77.85 & \pm & 11.75 & \\
\hline Malate dehydrogenase & 1.1.1.37 & 1115.42 & \pm & 90.90 & 1158.66 & \pm & 145.10 & \\
\hline \multicolumn{9}{|l|}{ Glutaminolysis } \\
\hline Glutaminase & 3.5.1.2 & 3.29 & \pm & 0.29 & 3.90 & \pm & 0.34 & b \\
\hline Glutamine synthetase & 6.3.1.2 & 0.68 & \pm & 0.25 & 0.80 & \pm & 0.25 & \\
\hline Glutamate dehydrogenase & 1.4.1.2 & 2.54 & \pm & 0.51 & 2.20 & \pm & 0.31 & \\
\hline Alanine transaminase & 2.6.1.2 & 3.21 & \pm & 0.50 & 3.31 & \pm & 0.03 & \\
\hline Aspartate transaminase & 2.6.1.1 & 78.67 & \pm & 5.36 & 79.12 & \pm & 13.17 & \\
\hline Malic enzyme & 1.1 .1 .40 & 7.61 & \pm & 0.61 & 9.87 & \pm & 0.62 & b \\
\hline Phosphoenolpyruvate carboxykinase & 4.1.1.32 & 138.64 & \pm & 15.33 & 131.48 & \pm & 11.42 & \\
\hline \multicolumn{9}{|l|}{ Miscellaneous } \\
\hline Acetate-CoA ligase & 6.2.1.1 & 2.01 & \pm & 0.13 & 2.69 & \pm & 0.34 & $b$ \\
\hline
\end{tabular}

${ }^{a}$ Mean values and $95 \%$ confidence intervals for three biological replicates.

b Significantly different from mock-infected cells as determined by Student's $t$-test $(p \leq 0.05)$. 


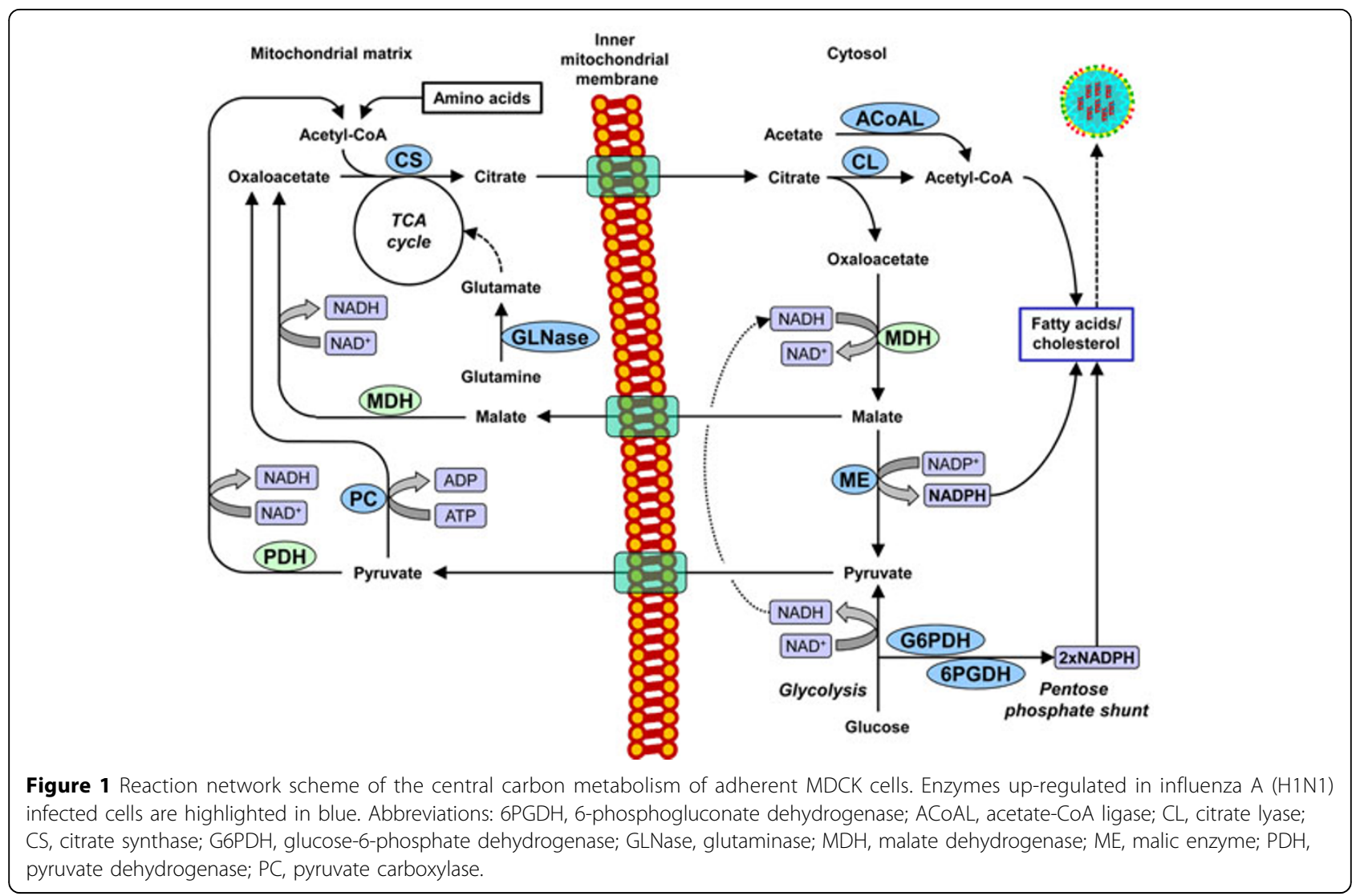

enzyme from glutaminolysis, $\mathrm{PC}$, citrate synthase, citrate lyase and NAD-ICDH from the citric acid cycle, and acetate-CoA-ligase (Figure 1). The fact that maximum enzyme activities in H1N1 infected cells were always higher than in mock-infected cells suggests an up-regulation of metabolic activities during early virus replication.

\section{Conclusions}

In the present work, the effect of an influenza virus infection on host cell metabolism was investigated. Experimental data clearly suggests a change in metabolism of cells infected with human influenza A (H1N1), i. e. an up-regulation of key metabolic enzyme activities in MDCK cells. This shift in metabolism is most likely required to compensate for the metabolic imbalance caused by viral replication. Interestingly, activity of some key enzymes producing NADPH and acetyl-CoA, a precursor needed for lipid and cholesterol biosynthesis, were increased by at least $20 \%$ in infected MDCK cells. Hence, fatty acid synthesis might play a crucial role for the replication of influenza viruses as they acquire lipid envelopes from their host cells.

\section{Acknowledgements}

This study is part of a FORSYS project (Grant No. 0313922). FORSYS is funded by the German Federal Ministry of Education and Research (BMBF). The funding is greatly acknowledged.

\section{Author details}

${ }^{1}$ Max Planck Institute for Dynamics of Complex Technical Systems, Bioprocess Engineering group, Sandtorstraße 1, 39106 Magdeburg, Germany. ${ }^{2}$ Chair for Bioprocess Engineering, Otto von Guericke University of Magdeburg, Universitätsplatz 2, 39106 Magdeburg, Germany.

Published: 22 November 2011

\section{References}

1. Thompson WW, Shay DK, Weintraub E, Brammer L, Cox N, Anderson LJ, Fukuda K: Mortality associated with influenza and respiratory syncytial virus in the United States. Jama-J Am Med Assoc 2003, 289(2):179-186.

2. Genzel $Y$, Reichl U: Continuous cell lines as a production system for influenza vaccines. Expert Rev Vaccines 2009, 8(12):1681-1692.

3. Nayak DP, Hui EKW, Barman S: Assembly and budding of influenza virus. Virus Res 2004, 106(2):147-165.

4. Cox NJ, Neumann G, Donis RO, Kawaoka Y: Orthomyxoviruses: Influenza. In Topley \& Wilson's Microbiology and Microbial Infections. Volume 3 and $4 .$. 10 edition. John Wiley \& Sons, Ltd;Mahy BWJ, ter Meulen V 2010:634-698 [http://onlinelibrary.wiley.com/doi/10.1002/9780470688618.taw0238/ abstract].

5. Ritter JB, Wahl AS, Freund S, Genzel Y, Reichl U: Metabolic effects of influenza virus infection in cultured animal cells: Intra- and extracellular metabolite profiling. Bmc Syst Biol 2010, 4.

6. Doroshenko A, Halperin SA: Trivalent MDCK cell culture-derived influenza vaccine Optaflu (Novartis Vaccines). Expert Rev Vaccines 2009, 8(6):679-688. 
7. Janke R, Genzel Y, Wahl A, Reichl U: Measurement of Key Metabolic Enzyme Activities in Mammalian Cells Using Rapid and Sensitive Microplate-Based Assays. Biotechnol Bioeng 2010, 107(3):566-581.

8. Genzel Y, Ritter JB, König S, Alt R, Reichl U: Substitution of glutamine by pyruvate to reduce ammonia formation and growth inhibition of mammalian cells. Biotechnol Progr 2005, 21(1):58-69[http://onlinelibrary. wiley.com/doi/10.1021/bp049827d/abstract].

9. Genzel Y, Behrendt I, König S, Sann H, Reichl U: Metabolism of MDCK cells during cell growth and influenza virus production in large-scale microcarrier culture. Vaccine 2004, 22(17-18):2202-2208.

doi:10.1186/1753-6561-5-S8-P129

Cite this article as: Janke et al.: Effect of influenza virus infection on key metabolic enzyme activities in MDCK cells. BMC Proceedings 2011 5(Suppl 8):P129.

\section{Submit your next manuscript to BioMed Central} and take full advantage of:

- Convenient online submission

- Thorough peer review

- No space constraints or color figure charges

- Immediate publication on acceptance

- Inclusion in PubMed, CAS, Scopus and Google Scholar

- Research which is freely available for redistribution

Submit your manuscript at www.biomedcentral.com/submit 